\title{
Net effect of competing vegetation on selected environmental conditions and performance of four spruce seedling stock sizes after eight years in Québec (Canada)
}

\author{
Robert JOBIDON*, Vincent RoY, Guillaume CYR \\ Ministère des Ressources naturelles, de la Faune et des Parcs du Québec, Direction de la recherche forestière, 2700 Einstein, \\ Sainte-Foy, Québec, G1P 3W8, Canada
}

(Received 24 June 2002; accepted 20 February 2003)

\begin{abstract}
A study was established in 1993 to determine the response of four black spruce (Picea mariana) and white spruce ( $P$. glauca) stock sizes on two sites located in Québec (Canada), each representing a different type of competing vegetation. At each site, a split-split-plot design with 15 to 17 replicates was used, in which the presence of competition (weedy and bare plots), seedling initial size, and spruce species were assigned respectively to the whole plot, the subplot, and the sub-subplot. Larger initial seedling size provided a greater competitive ability for light and had higher growth rates than the standard stock size for both species. Growth gains from combining plantation of large stock with vegetation control were multiplicative. Non-crop vegetation significantly lowered the seasonal profile of 10 -cm depth soil temperature on both sites. This study shows that early release treatment is required on sites dominated by raspberry-hardwood competition complex and planting large spruce stock on such harsh competition sites will help reduce the need for repeated vegetation control.
\end{abstract}

large seedling / competition / vegetation control / soil temperature / release treatment

Résumé - Effet net de la végétation de compétition sur certaines conditions environnementales et sur la performance de quatre dimensions de plants d'épinette après huit ans. Une étude a été établie en 1993 afin de déterminer la performance de quatre dimensions de semis d'épinette noire (Picea mariana) et d'épinette blanche ( $P$. glauca) mis en terre sur deux sites situés au Québec (Canada), chacun représentant un type de compétition. À chaque site d'étude, un dispositif en tiroirs subdivisés avec 15 et 17 répétitions a été utilisé, avec la présence de compétition, la dimension initiale des semis et l'espèce, assignées à la parcelle principale, la sous-parcelle et la sous sous-parcelle, respectivement. Les plants de fortes dimensions (PFD) ont reçu plus de lumière et ils affichaient une meilleure croissance que le plant de dimension standard. Les gains de croissance découlant de la combinaison d'une plantation de PFD avec contrôle de la compétition ont été multiplicatifs. La végétation de compétition a significativement abaissé le profil saisonnier de la température du sol mesurée à $10 \mathrm{~cm}$ de profondeur. Cette étude démontre qu'un dégagement hâtif est nécessaire sur les stations caractérisées par une forte compétition de framboisiers et de feuillus intolérants. De plus, sur ces mêmes stations, un reboisement avec des PFD devrait limiter le besoin de répéter les dégagements mécaniques.

plant de fortes dimensions / compétition / gestion de la végétation / température du sol / dégagement mécanique

\section{INTRODUCTION}

Clear cutting modifies a number of environmental variables, including soil temperature and moisture [6], nitrogen availability through mineralization, and nitrification [41]. These changes contribute to the creation of new regeneration niches particularly suitable for numerous opportunistic species. This non-crop vegetation can seriously affect spruce plantations by intercepting light, often considered the resource most commonly affected by neighbouring vegetation in north-eastern America [8]. By intercepting a large part of incoming solar radiation, non-crop vegetation also plays a role in modifying the soil thermal regime of spruce plantations [12]. Low soil temperatures are recognized as one of the major constraints in establishing seedlings on boreal reforestation sites [4]. As pointed out by Groot and King [3], an improved understanding of the physical environment of newly planted tree seedlings will contribute to increase our knowledge on the effects of silvicultural treatments, which will be particularly useful to correlate with critical levels of one or another tree seedling growth process.

Following plantation, release treatments of newly planted conifers are usually carried out to optimize resource availability for the crop species. However, over the last two decades, environmentalists and social groups in parts of Canada have demanded that use of herbicides and aerial spraying on regenerating forest sites be reduced. The current forest policy in the Province of Québec forbids the use of herbicides which

\footnotetext{
*Corresponding author: robert.jobidon@mrnfp.gouv.qc.ca
} 
has caused changes in forestry practices. In order to reduce the acreage where mechanical release treatments are needed during the first few years of planting, new silvicultural approaches are implemented such as (1) reducing to one year the timeframe between the final harvest and seedling plantation, hence avoiding planting on sites already invaded by competing species; (2) integrating autecological characteristics of competing species in forestry practices [9-11]; and (3) producing and planting large spruce seedling stock on highly competitive sites [27].

Planting large conifer seedling stock to reduce competing vegetation effects on survival and growth has already shown positive results elsewhere with various species, for example Douglas-fir (Pseudotsuga menziesii (Mirb.) Franco) [25, 26], radiata pine (Pinus radiata D. Don) [21, 35], slash pine (Pinus elliottii Engelm. var. elliottii) [32], and Sitka spruce (Picea sitchensis (Bong.) Carr.) [31]. Previous studies with black spruce (Picea mariana (Mill.) B.S.P.) and white spruce (Picea glauca (Moench) Voss) large seedling stock, two commonly planted species across Canada, specifically examined transplant shock and initial establishment in growth chambers [36], experimental sand beds [15], and experimental field sites $[13,16]$.

Additional investigations must be conducted to assess the cumulative effect over time of competition on field performance of various large spruce seedling stock. The present study addressed more specifically selecting an "optimum" seedling size production for two contrasting environments, each representing a type of competing vegetation commonly found in eastern Canada. To achieve this goal, it is important to first include the nursery production of various stock sizes, instead of grading seedlings within a given population; and second, to evaluate competing vegetation effects by means of competition - free seedlings, instead of release treatments. The objectives of this study were first, to quantify the net effect of non-crop vegetation on soil temperature and light attenuation during the first five growing seasons. Secondly, it was to quantify the effect of competing vegetation, stock size, species and their interactions on seedling survival and growth, eight years after plantation.

\section{MATERIALS AND METHODS}

The investigations were conducted in the Province of Québec (Canada) on two experimental study sites, each representing a different bioclimatic domain and a different type of competing vegetation complex. Site $1\left(46^{\circ} 8^{\prime} \mathrm{N}, 72^{\circ} 2^{\prime} \mathrm{W}\right)$ is a recently abandoned agricultural field, located within the sugar maple (Acer saccharum Marsh.) - basswood (Tilia americana L.) bioclimatic domain [28]. The second study site $\left(47^{\circ} 58^{\prime} \mathrm{N}, 68^{\circ} 26^{\prime} \mathrm{W}\right)$, named site 3 after Jobidon et al. [13], is a forest site recently harvested located within the balsam fir (Abies balsamea (L.) Mill.) - yellow birch (Betula alleghaniensis Britt.) bioclimatic domain [28]. A mature stand of balsam fir - black spruce was clearcut in the summer of 1992 and the site was prepared by disk trenching in the fall of 1992 . The soil of the two sites is classified as a humo-ferric podzol [29]. Soil-size particle analyses are given in Jobidon et al. [13].

Four sizes of containerized black spruce and white spruce seedlings were obtained from provincial forest nurseries. The experiment included one regular stock size produced in containers of 45 cavities of $110 \mathrm{~cm}^{3}$ each $(110 \mathrm{cc})$, and three new large stock sizes produced
Table I. Initial morphological characteristics (mean and standard deviation) of the four white spruce and black spruce stock sizes at time of planting on the two experimental sites.

\begin{tabular}{|c|c|c|c|}
\hline \multirow{2}{*}{$\begin{array}{l}\text { Experimental site } \\
\text { (species, stock size) }\end{array}$} & \multicolumn{3}{|c|}{ Characteristics at time of planting } \\
\hline & Height $(\mathrm{cm})$ & Diameter $(\mathrm{mm})$ & Height/diameter \\
\hline \multicolumn{4}{|l|}{ Site 1} \\
\hline \multicolumn{4}{|l|}{ White spruce } \\
\hline $110 \mathrm{cc}$ & $22.2(3.3)$ & $4.0(0.7)$ & $56.1(10.6)$ \\
\hline $340 \mathrm{cc}$ & $35.7(6.8)$ & $6.5(1.1)$ & $56.3(11.6)$ \\
\hline $700 \mathrm{cc}$ & $42.8(9.3)$ & $8.6(1.2)$ & $50.2(11.3)$ \\
\hline $1000 \mathrm{cc}$ & $47.3(8.5)$ & $9.5(1.2)$ & $50.6(10.1)$ \\
\hline \multicolumn{4}{|l|}{ Black spruce } \\
\hline $110 \mathrm{cc}$ & $22.5(3.1)$ & $3.1(0.5)$ & $75.1(14.1)$ \\
\hline $340 \mathrm{cc}$ & $46.6(7.5)$ & $5.6(1.1)$ & $87.0(23.5)$ \\
\hline $700 \mathrm{cc}$ & $58.6(7.6)$ & $7.6(1.2)$ & $78.7(12.7)$ \\
\hline $1000 \mathrm{cc}$ & $67.7(12.7)$ & $9.6(1.2)$ & $71.5(15.0)$ \\
\hline \multicolumn{4}{|l|}{ Site 3} \\
\hline \multicolumn{4}{|l|}{ White spruce } \\
\hline $110 \mathrm{cc}$ & $20.2(3.5)$ & $4.6(0.7)$ & $45.1(9.1)$ \\
\hline $340 \mathrm{cc}$ & $34.3(7.2)$ & $7.0(1.1)$ & $49.7(10.0)$ \\
\hline $700 \mathrm{cc}$ & $39.1(8.2)$ & $9.1(1.2)$ & $43.1(8.7)$ \\
\hline $1000 \mathrm{cc}$ & $42.8(10.3)$ & $9.6(1.3)$ & $45.2(16.3)$ \\
\hline \multicolumn{4}{|l|}{ Black spruce } \\
\hline $110 \mathrm{cc}$ & $20.4(3.5)$ & $3.7(0.6)$ & $56.3(10.9)$ \\
\hline $340 \mathrm{cc}$ & $44.3(6.6)$ & $6.5(0.8)$ & $69.2(11.0)$ \\
\hline $700 \mathrm{cc}$ & $53.8(7.1)$ & $8.3(1.0)$ & $65.3(9.5)$ \\
\hline $1000 \mathrm{cc}$ & $62.3(12.3)$ & $10.3(1.4)$ & $61.4(12.4)$ \\
\hline
\end{tabular}

in containers of $45-340 \mathrm{cc}, 15-700 \mathrm{cc}$, and $12-1000 \mathrm{cc}$. All seedlings were grown over a 2-year period, but larger stock types were produced on a more intensive regime involving greenhouse culture. Cultural conditions are described in Lamhamedi et al. [15]. Seedlings were planted in May 1993 on the experimental sites shortly after snowmelt. Total height $(\mathrm{cm})$ and diameter $(\mathrm{mm})$ at ground level were measured for all seedlings immediately after planting with respect to each stock size (Tab. I).

For each site, a split-split-plot design organized in a completely randomized block design was used to lay out field plots. Seventeen (17) pairs (blocks) of rectangular plots $(9 \mathrm{~m} \times 17 \mathrm{~m})$ were laid out on the two sites with 2 -m buffers between each plot. On site 1, two pairs of plots were excluded soon after establishment due to excessively poor drainage. Each species was randomly assigned to a half of each plot; within each of these subplots, four rows were laid out and assigned at random to one of the four sizes of seedlings. Within each row or sub-subplot, seven seedlings of a given size and species were planted $2 \mathrm{~m}$ apart. To assess the effect of competition on spruce seedling growth, repeated vegetation control (herbicides and manual) was applied to a single plot chosen at random within each pair of plots, to maintain bare-ground conditions during the study period. Following vegetation control, the plant debris were removed from the plot to avoid an insulating effect from this organic material. More details on vegetation control applications are provided in Jobidon et al. [13]. 
During the summer of 1994, surveys of the competing vegetation cover were carried out at the two sites, using three randomly-distributed $1 \mathrm{~m}^{2}$ subplots in each plot with vegetation. On site 1 , the abandoned agricultural field, a cover of grassy (Festuca, Agrostis, and Poa), composite (Solidago graminifolia (L.) Salisb.), and leguminous (Vicia cracca L.) species developed. On site 3, the vegetation complex was characterized by a cover of red raspberry (Rubus idaeus L.) associated with mountain maple (Acer spicatum Lam.) and red maple (A. rubrum L.). Details on the frequency and density of the species forming the ground cover at each site are given in Jobidon et al. [13].

Measuring photosynthetically active radiation (PAR) at a single time at the point of maximum canopy development is suggested as an alternative to visual estimates of vegetation cover to assess the competitive status of newly planted conifers $[7,8,37]$. Therefore, PAR was measured once for each seedling in plots covered by competing vegetation in July 1995 on site 1, and in July 1993, 1994, 1995, 1996, and 1997 on site 3, using a sunfleck ceptometer (Decagon Devices, Pullman, WA). Each time, orthogonal measurements were made at the terminal bud and mid-height of all seedlings [8]. One further measurement was made above the vegetation canopy. Average upper-crown readings were expressed as a percentage of the abovecanopy light level (\% PAR).

At site 3, according to the relatively low quantity of light reaching the seedlings during the second growing season, a mechanical release treatment was carried out in June of the third growing season on 8 blocks randomly selected among the 17 blocks of the experiment. Eight (8) plots with competition were released using brushsaws and vegetation was allowed to regrow afterwards. Therefore, the experimental design on site 3 was a split-split plot organized in an incomplete block design and consisted of 8 pairs of released plots and competitionfree plots, and 9 pairs of plots with competition and competition-free plots.

The $10 \mathrm{~cm}$-depth soil temperature was monitored from the first to the fifth growing season in the centre of each of 12 plots (6 plots without vegetation and 6 others with vegetation) at each site with use of thermistor (temperature probe, model 107B, Campbell Scientific, Logan, UT). Probes were buried at maximum distance from seedlings, which is approximately $1.4 \mathrm{~m}$. Data were averaged hourly and recorded on a datalogger (model CR-10, Campbell Scientific, Logan, UT). For both treatments and both sites, the number of days with a mean daily root - zone soil temperature above $20^{\circ} \mathrm{C}$ were calculated. The threshold of $20^{\circ} \mathrm{C}$ was chosen because it is generally recognized as the soil temperature optimum for conifer seedling root growth [19, 40]. Differences in mean daily temperature were also calculated. Results from the first (1993), the third (1995), and the fifth (1997) growing seasons are presented. The growing season is defined as follows: June 1st to September 7 for the 1995 and 1997 seasons at both sites and for the 1993 season at site 1, and from July 1st to September 7 for the 1993 season at site 3 .

Total height and diameter at $15 \mathrm{~cm}$ above ground level were measured on all seedlings in October 2000, after eight growing seasons. A conic volume index was calculated on each one using the formula: conic volume $=\pi R^{2} \mathrm{H} / 3$ (or: $0.2618 \mathrm{D}^{2} \mathrm{H}$ ). Data were averaged from 7 seedlings in each sub-sub-plot.

Experimental sites were not statistically compared. Statistical analyses were performed according to the experimental design using the procedure MIXED from SAS [18]. The quantity of light (\% PAR) reaching the mid-upper crown of seedlings with competition at site 1 was analyzed using an ANOVA after angular transformation of the data. To evaluate the effect of the release treatment on the quantity of light available at the tree seedling level at site 3 , fifth-year data from released plots and plots with competition were also compared using an ANOVA. Given that \% PAR was measured each year on site 3, a profile analysis (ANOVAR) was also performed. A similar ANOVAR was used to examine competing vegetation effects on mean daily soil temperature over time. The likelihood-based estimation approach of PROC MIXED to fit heterogeneous variance models takes into account the correlation between successive times (withinsubject heterogeneity) by use of an autoregressive order 1 covariance structure. A repeated measures analysis of variance (RMANOVA) was used for daily comparisons of the mean soil temperature between the two vegetation treatments, by taking into account the entire seasonal profile.

Eighth-year height, diameter and volume index were subjected to an analysis of variance (ANOVA). Volume index data on site 3 were transformed (square root) for analysis. For seedling eighth-year survival analysis, the macro GLIMMIX from SAS was used, taking into consideration the binomial character of this variable [18]. For all variables, when pertinent, means were compared by a Fisher's protected LSD test at a 0.05 level of significance.

\section{RESULTS}

\subsection{Site 1 (the abandoned agricultural field; gramineous vegetation complex)}

On this site, a significant stock size effect was detected $(p<$ 0.001 ) on the quantity of light reaching the mid-upper crown of seedlings with competition during the third growing season. From the smallest to the largest stock size, PAR received in the mid-upper seedling crown averaged 67.9 (a), 78.8 (b), 84.0 (c), and 86.2 (c) \% of full sunlight (means followed by the same letter are not significantly different).

For plots without vegetation, the first, third and fifth growing seasons were respectively characterized by 12,29 and 0 days with a daily mean root - zone soil temperature above $20{ }^{\circ} \mathrm{C}$, while plots with competition had 0 days for the three years. Non-crop vegetation significantly influenced the seasonal profile of soil temperature, from the first to the fifth growing season of this study, as revealed by the significant Competition $\times$ Day interaction $(p<0.001)$. The presence of vegetation maintained cooler soil during the summer period. From Julian Day 152 to 250 , a mean difference of $0.9{ }^{\circ} \mathrm{C}$ was noted the first year, $2.5^{\circ} \mathrm{C}$ the third year (Fig. $1 \mathrm{~A}$ ), and $1.0^{\circ} \mathrm{C}$ the fifth year. During that period of time, maximum differences averaged $2.2{ }^{\circ} \mathrm{C}$ the first year (Julian Day 239), $3.8^{\circ} \mathrm{C}$ the third year (Julian Day 181), and $1.7{ }^{\circ} \mathrm{C}$ the fifth year (Julian Day 183).

As expected, the initial differences in seedling size between the four stock types were still evident after eight years. Stock size performance was similar for both spruce species, but it was influenced by vegetation treatments, as shown by significant Competition $\times$ Stock size interactions (Tab. II). Volume index (data not shown) and diameter for all stock sizes were affected by vegetation cover, but in a greater way for the smallest stock size $(110 \mathrm{cc})$ (Fig. 2A). Diameter was 1.5 and 1.2 times larger on competition free plots, compared to plots with competition, for the 110 and $340 \mathrm{cc}$ stock sizes respectively, indicating that the $110 \mathrm{cc}$ stock suffered more from competition than the $340 \mathrm{cc}$ stock. Height was not affected by vegetation cover, except for $110 \mathrm{cc}$ stock (Fig. 2B). Regardless of stock type, black spruce had a significantly smaller diameter $(55.2 \mathrm{~mm})$ and volume index $\left(2600 \mathrm{~cm}^{3}\right)$ than white spruce in the presence of competition $\left(62.5 \mathrm{~mm}, 3312 \mathrm{~cm}^{3}\right)$. Eight years after plantation, the overall survival rate was $96 \%$ 

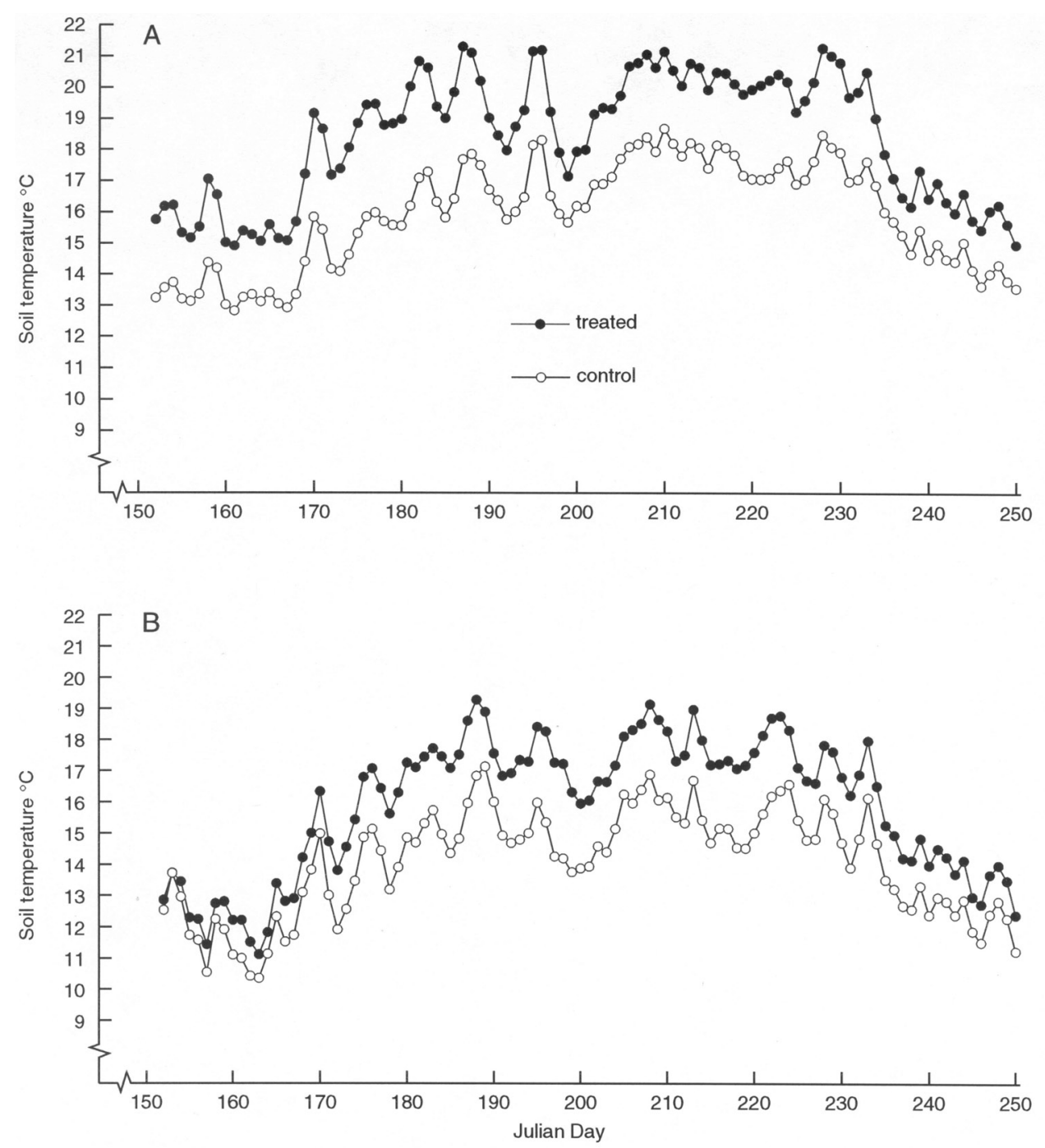

Figure 1. Daily mean soil temperature seasonal profiles at a $10-\mathrm{cm}$ depth, as influenced by non-crop vegetation $(\bullet-\bullet$ treated, without competition; ○-० control, with competition) during the third growing season after spruce planting on sites $1(\mathrm{~A})$, and $3(\mathrm{~B})$.

regardless of vegetation and spruce species (Tab. II). Survival of the $700 \mathrm{cc}$ stock size (97\%) was slightly greater than the $340 \mathrm{cc}$ and $110 \mathrm{cc}(93 \%)$.

\subsection{Site 3 (the forest site; raspberry-hardwood vegetation complex)}

The ANOVAR performed to evaluate competing vegetation effects (third-year release treatment excluded) on the quantity of light reaching the mid-upper crown of spruce seedlings during the initial five-year establishment period of the trial, revealed a significant Species $\times$ Time linear interaction $(p<0.001)$. This interaction shows a linear profile of variation over time for both species which is not parallel for the two species. During the first three years, black spruce seedlings received more light than white spruce, but a reverse pattern occurred the ensuing years. The lack of a significant Stock size $\times$ Time interaction $(p=0.85)$ is of interest because the profiles of variation over time among the four stock sizes were parallel (Fig. 3). This indicates that initial size differences among the four stock sizes in the mean quantity of light they received were maintained over time. The ANOVA performed on the fifth-year data of light reaching the mid-upper crown of seedlings to evaluate the effect of the release treatment revealed a significant Vegetation $\times$ Stock size interaction $(p=$ 0.007). The fifth year, released seedlings of all stock sizes received significantly more light than unreleased seedlings. From the smallest to the largest stock size, released seedlings received 36.6 (a), 59.3 (b), 67.8 (c), and 67.9 (c) \% of full sunlight, respectively, while unreleased seedlings received 18.7 (a), 26.3 (b), 29.7 (bc), and 33.8 (c) \% of full sunlight, respectively (within a given vegetation treatment, means followed by the same letter are not significantly different).

For both plots with and without vegetation, the first, third and fifth growing seasons were all characterized by 0 days with a daily mean root - zone soil temperature above $20^{\circ} \mathrm{C}$. During the first growing season, vegetation treatments did not influence the seasonal profile of soil temperature, as revealed by the lack of significant Competition $\times$ Day interaction $(p=0.99)$. However, non-crop vegetation significantly influenced third and fifth year seasonal soil temperature profiles $(p<0.001)$. As observed on site 1 , vegetation maintained 
Table II. $P$ values and degrees of freedom (df) from the analysis of variance of survival, diameter, height and volume index for seedlings planted on sites 1 and 3 .

\begin{tabular}{lrrrrr}
\hline Effect & df & Survival & Diameter & Height & Volume \\
\hline Site 1 & & & & & \\
$\quad$ Competition (C) & 1 & 0.817 & $<0.001$ & 0.019 & $<0.001$ \\
Species (S) & 1 & 0.509 & 0.016 & 0.114 & 0.193 \\
C $\times$ S & 1 & 0.115 & 0.047 & 0.091 & 0.043 \\
Stock size (Size) & 3 & 0.009 & $<0.001$ & $<0.001$ & $<0.001$ \\
C $\times$ Size & 3 & 0.885 & $<0.001$ & $<0.001$ & 0.002 \\
S $\times$ Size & 3 & 0.097 & 0.235 & 0.666 & 0.429 \\
C $\times$ S $\times$ Size & 3 & 0.429 & 0.287 & 0.156 & 0.297 \\
Site 3 & & & & & \\
Competition (C) & 2 & $<0.001$ & $<0.001$ & $<0.001$ & $<0.001$ \\
Species (S) & 1 & $<0.001$ & 0.018 & $<0.001$ & $<0.001$ \\
C $\times$ S & 2 & 0.128 & 0.255 & 0.096 & 0.056 \\
Stock size (Size) & 3 & 0.093 & $<0.001$ & $<0.001$ & $<0.001$ \\
C $\times$ Size & 6 & 0.096 & $<0.001$ & $<0.001$ & $<0.001$ \\
S $\times$ Size & 3 & 0.059 & 0.019 & 0.003 & 0.037 \\
C $\times$ S $\times$ Size & 6 & 0.060 & 0.276 & 0.181 & 0.454 \\
\hline
\end{tabular}

cooler soil, except at the beginning of the third (Julian Days 152 to $159(p>0.080), 163(p=0.132)$, and $164(p=0.175))$ and fifth growing seasons (Julian Days 152 to $173(p>$ $0.053)$ ). For the entire growing season, a mean difference of $1.8^{\circ} \mathrm{C}$ was noted the third year (Fig. 1B), and $1.2{ }^{\circ} \mathrm{C}$ the fifth year. At the third year, a maximum difference of $3.0^{\circ} \mathrm{C}$ was reached on Julian Day 198, and at the fifth year, a maximum difference of $2.2^{\circ} \mathrm{C}$ was reached on Julian Day 196.

The growth response of seedlings differed among the four stock sizes in relation to spruce species and vegetation treatment (Tab. II). After eight years, black spruce seedlings had significantly greater height and volume index (data not shown) than white spruce, except for the standard $110 \mathrm{cc}$ stock
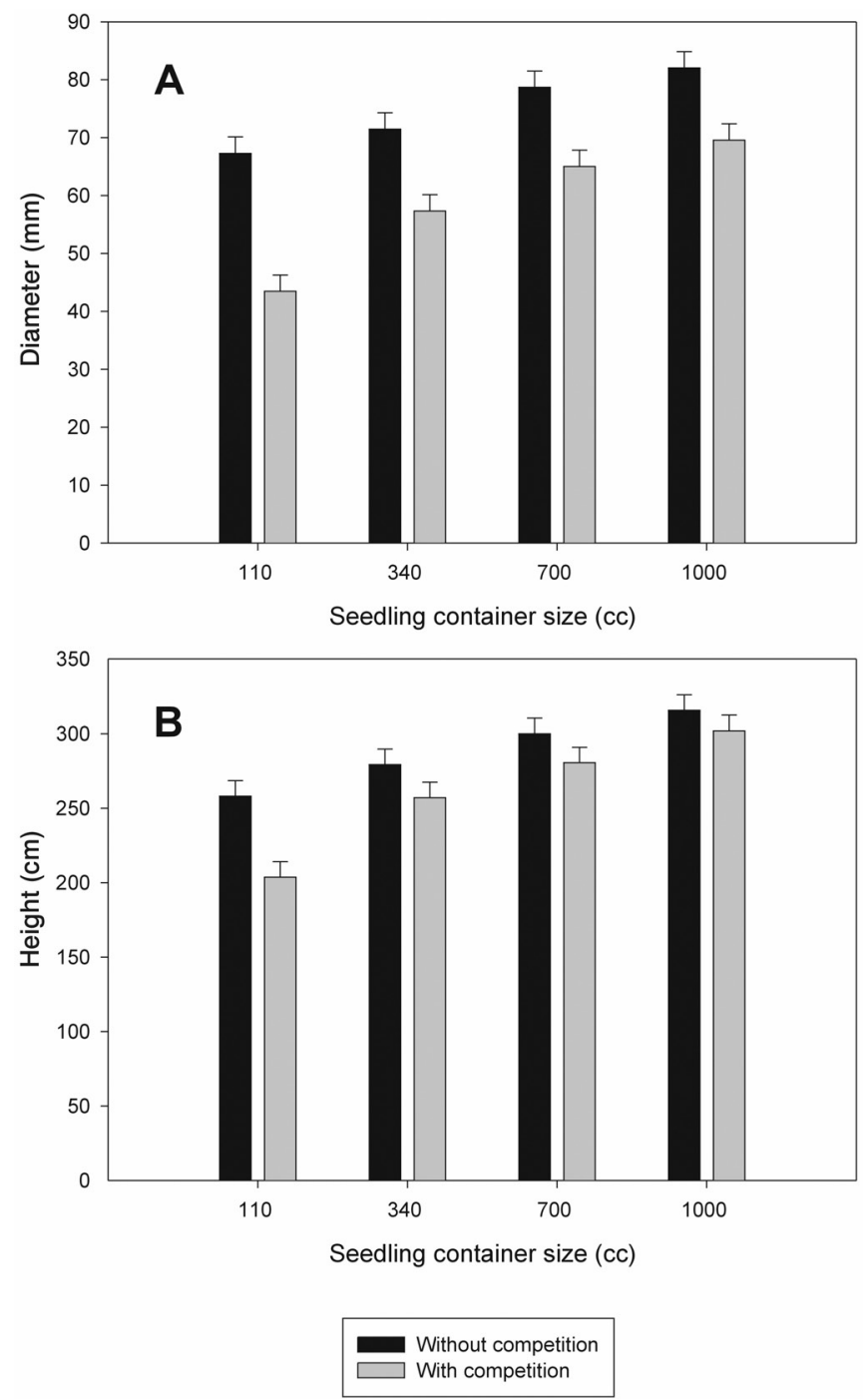

Figure 2. Diameter (A) and height (B) 8 years after plantation on site 1 without competition and with competition for four seedling container sizes.

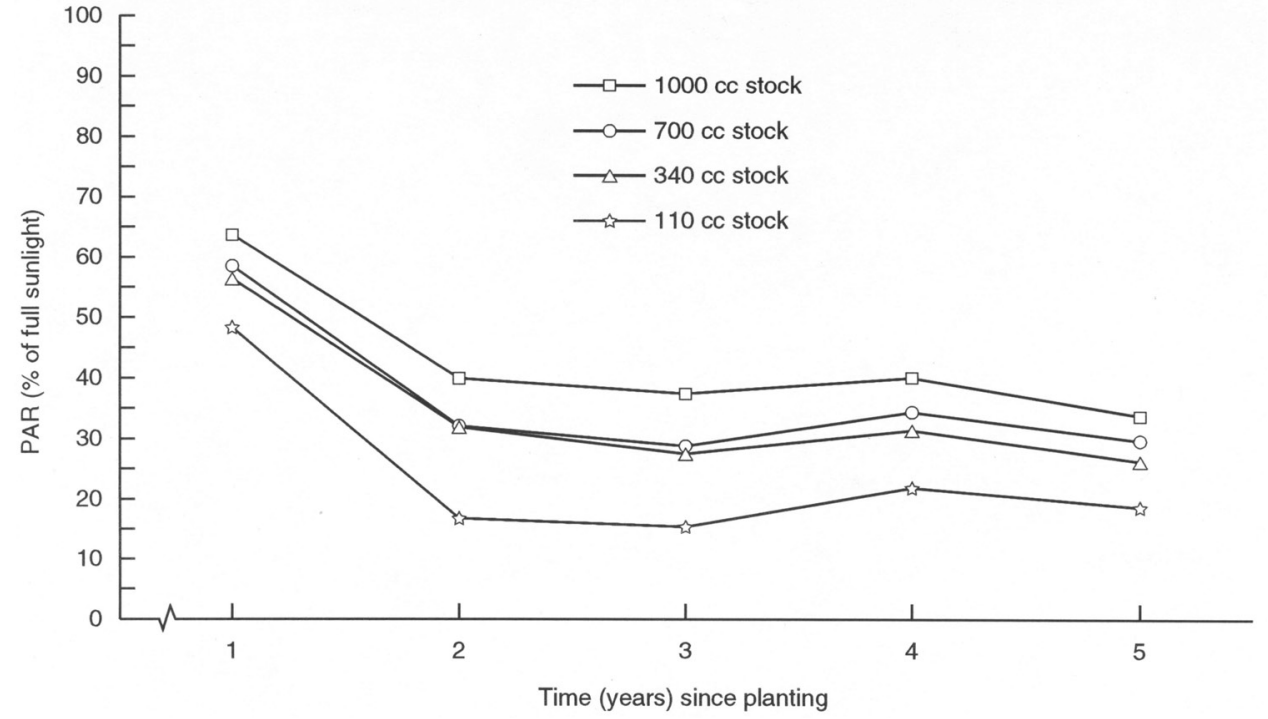

Figure 3. Mean quantity of light (PAR, \% of full sunlight) reaching the mid-upper crown of four spruce seedling stock sizes during the first five growing seasons after planting on site 3 (black spruce and white spruce species confounded). 

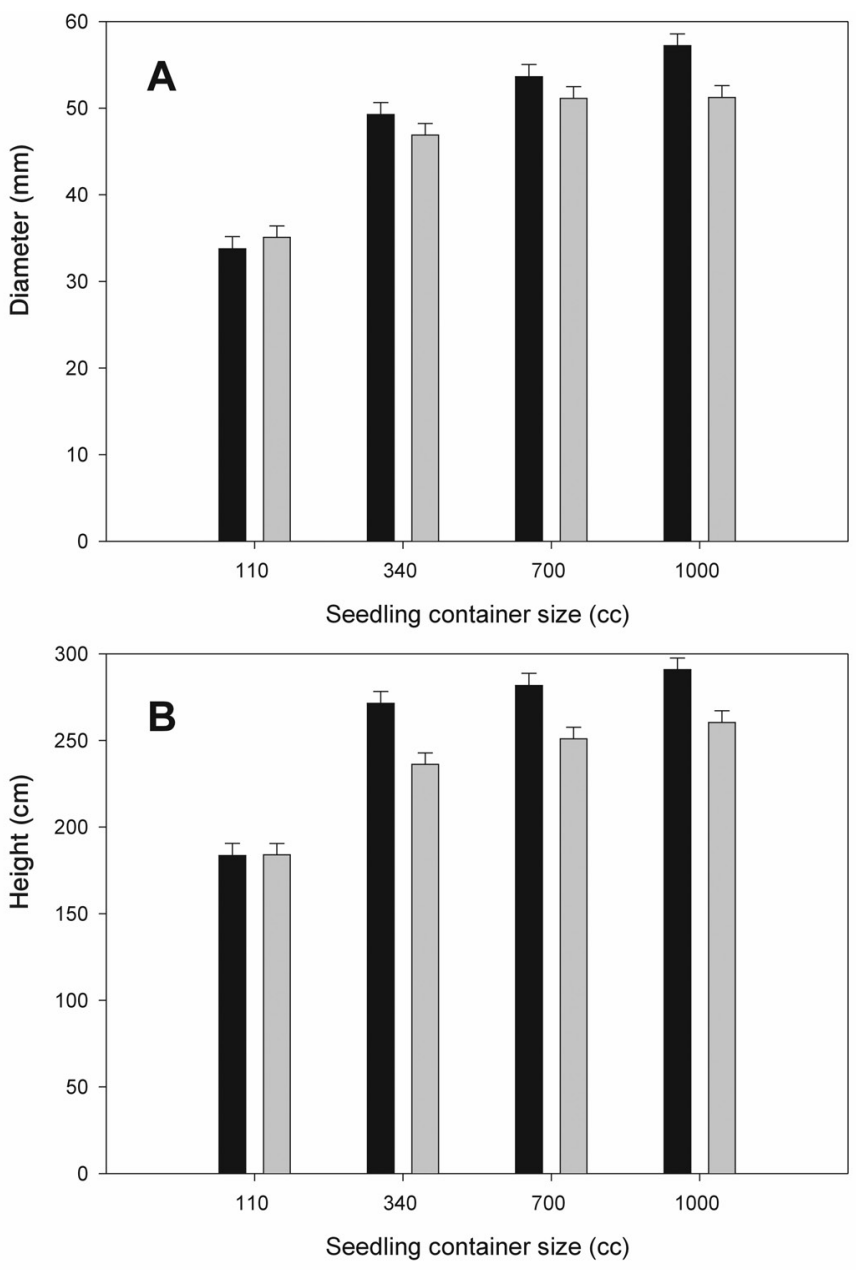

Black spruce
White spruce

Figure 4. Diameter (A) and height (B) 8 years after plantation on site 3 for black spruce and white spruce for four seedling container sizes.

(Fig. 4B). However, diameter was similar for both species, except for the $1000 \mathrm{cc}$ stock where black spruce was significantly larger than white spruce (Fig. 4A). For each of the four stock sizes, height, diameter and volume index (data not shown) were bigger on competition - free plots followed by the release treatment and no vegetation treatment (Figs. $5 \mathrm{~A}$ and 5B). For each vegetation treatment, the $110 \mathrm{cc}$ stock had a significantly lower diameter, height and volume index, as opposed to the larger stocks which showed only slight differences among them. Vegetation had an extremely severe effect on diameter growth on this site. Seedlings with competition had a diameter averaging 2.5 times smaller than without competition. Eight years after plantation, survival rate averaged $84 \%$ and it did not differ between stock types. However, seedling survival was significantly different among vegetation treatments and species (Tab. II), averaging 66\%, 84\% and $94 \%$ for no control, release and vegetation control, respec-
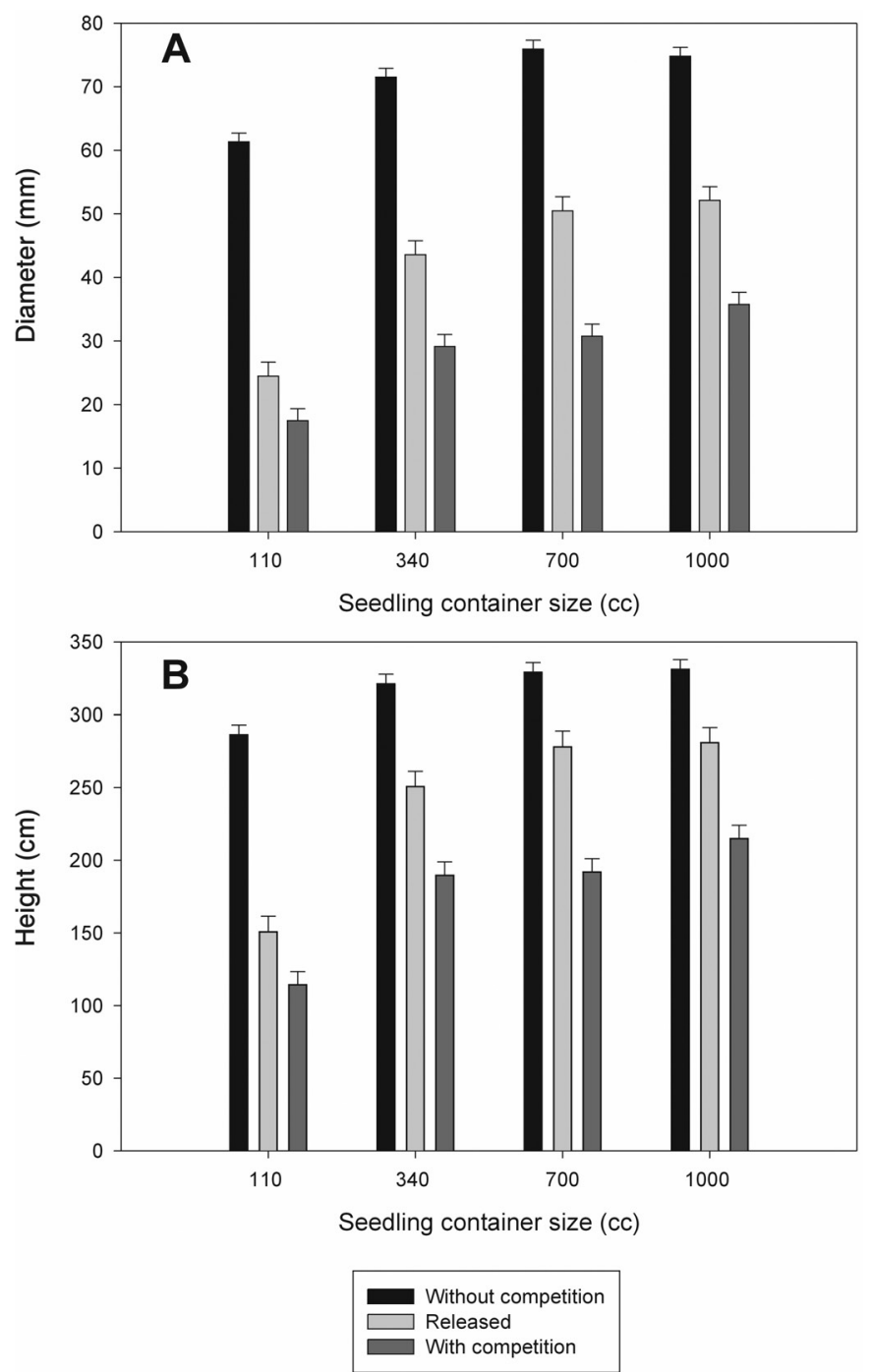

Figure 5. Diameter (A) and height (B) 8 years after plantation on site 3 without competition, released after 3 years and with competition for four seedling container sizes.

tively. Black spruce and white spruce averaged a survival rate of $79 \%$ and $89 \%$, respectively.

\section{DISCUSSION}

On the two study sites, eighth-year height and diameter of the spruce seedlings were related to stock size. For each of the vegetation treatments, the standard stock size $(110 \mathrm{cc})$ had significantly lower growth parameters than the larger stock types. Initial diameter has been related to seedling performance in other studies [20, 32, 33]. However, our results support the hypothesis of South and Mitchell [32] that a biological limit to achieving gains is reached at a given tree seedling size. The present study shows that the limit is lowered in the presence of a growth constraint such as competition. Without any competition, increasing the stock size beyond the $700 \mathrm{cc}$ stock did not 
further enhance the diameter. In plots with vegetation, both height and diameter differed among the stock sizes, and most of the size increments beyond the 340 cc stock led to non significant or relatively small growth improvements over the study period compared to the growth improvement observed between the $110 \mathrm{cc}$ and the $340 \mathrm{cc}$ stock. At the time of planting, the largest size differences were noted between the $110 \mathrm{cc}$ and the $340 \mathrm{cc}$ stock sizes (see Tab. I). The differences observed after eight years for height and diameter growth among the four stock sizes followed the same pattern. This indicates that such a biological limit is likely the result of an equilibrium between growth potential or photosynthetic capacity of a given stock and capacity of environmental resources uptake. In the present study, we used large spruce stock from the same seed lot. Differences in the stock genetics were not a source of variation in growth potential and could not account for the differences observed. This effect could not be attributed either to a better mineral nutrition of the $340 \mathrm{cc}$ stock, as opposed to the $110 \mathrm{cc}$ stock. On site 1, no significant Vegetation $\times$ Stock size interactions were found for foliar $\mathrm{N}, \mathrm{P}$ and $\mathrm{K}$ concentrations after five growing seasons (data not shown), indicating that vegetation affected almost equally spruce seedling nutrition among the four stock sizes. Although a significant interaction was found for foliar $\mathrm{N}$ concentration at site 3 after five growing seasons (data not shown), comparison of means across the four stock sizes does not support the growth response obtained, neither could it be attributed to increased water stress experienced by the larger seedlings in contrast to the smaller ones [13].

In plots with competition, the growth pattern observed among the four stock sizes is explained by the quantity of light available for tree seedling growth, with respect to each stock size. At the two experimental sites, it appears that the mean quantity of light available for tree seedling growth during the initial establishment phase increased more significantly at the first increment in stock size than at any further increment beyond the $340 \mathrm{cc}$ stock (see Fig. 3 showing data for site 3 ). This study evidenced that the difference in size between the $110 \mathrm{cc}$ stock and the $340 \mathrm{cc}$ stock was large enough to provide a significant advantage whether in presence of gramineous or raspberry-hardwood vegetation complex. Other studies have also shown benefits of planting large conifer stock in various competing vegetation types [23-25, 43].

On both sites, the competitive advantage of initial seedling size on growth was obvious as revealed by significant Competition $\times$ Stock size interactions (Tab. II, Figs. 2 and 5). Moreover, competition and stock type effects were multiplicative in our study. For example, in the competition-free plots of site 3, the diameter difference between the $340 \mathrm{cc}$ and the $110 \mathrm{cc}$ stock types averaged $10 \mathrm{~mm}$, which is the beneficial effect of the larger stock type. Releasing the $110 \mathrm{cc}$ stock increased the diameter by $7 \mathrm{~mm}$. In the released plots, the diameter of the $340 \mathrm{cc}$ stock was larger than the released $110 \mathrm{cc}$ stock by $26 \mathrm{~mm}$, which is 1.5 times greater than the sum of the simple effects. This illustrates the multiplicative effect we could expect from planting a larger spruce seedling combined with a release treatment. In opposition, a study comparing the gains from intensive management with the benefits from improved nursery practices concluded that early gains from combining intensive management and planting large-diameter seedlings appeared to be additive for loblolly pine (Pinus taeda L.) [33].

The detrimental effect of competing vegetation on seedling growth is likely a partial result of its effect on light attenuation and hence on soil temperature. Light levels observed in plots with competition were rapidly below $60 \%$, a threshold for optimal spruce growth [8]. Also, the magnitude of the soil temperature decrease owing to competition is likely to affect seedling growth since temperature levels were generally below the $20{ }^{\circ} \mathrm{C}$ optimum. Brand and Janas [1] reported that $10-\mathrm{cm}$ depth soil temperature differences of 2 to $3{ }^{\circ} \mathrm{C}$ significantly affected growth of white spruce and white pine (Pinus strobus L.).

Competing vegetation affected seedling growth differently on the two experimental sites according to the vegetation complex. In plots without vegetation, small differences in diameter ( 75 vs. $71 \mathrm{~mm}$ ) between the two experimental sites can be explained by local climatic conditions and site quality. However, in plots with competition, the raspberry-hardwood vegetation complex on site 3 reduced eighth-year spruce diameter by a factor 2.5 , compared to 1.3 on site 1 . The large difference in growth response obtained between the two vegetation complex is attributed to the resulting microenvironment caused by the specific nature of the vegetation types. During the third growing seasons, PAR levels over $60 \%$ indicate that seedlings were already free-to-grow in the gramineous vegetation complex, which has a finite height growth. On the contrary, the non-finite height growth pattern of species in the raspberryhardwood complex maintained low levels of light availability and greatly reduced seedling height and diameter growth. Such results are in accordance with the findings of Küßner et al. [14] who pointed out that growth response of black spruce to competition and site characteristics is explained by important site-specific and distinct species-specific competition-crop relationships.

The different soil temperature profiles during the establishment phase of non-crop vegetation on the two sites illustrates the different competition dynamics. The first growing season, the gramineous vegetation at site 1 developed rapidly, thus had an effect from Julian Day 181 (June 30th) while it takes at least the entire first growing season for the raspberry - hardwood competition to develop to a sufficient level to affect soil temperature. For third and fifth year, vegetation did not significantly affect soil temperature during the first days in spring and early summer at site 3 . This is explained by the nature of the non-crop vegetation cover and local climatic conditions. Indeed, in early summer, non-crop vegetation foliage has not yet completed its growth and the exchange in radiant energy shifted later in the growing season from the ground surface to the vegetation cover [39]. Such result indicates that initiation of spruce height growth was not impaired by vegetation effects on soil temperature in the context of raspberry - hardwood competition. However, the gramineous vegetation complex modified the soil thermal regime differently by forming a thermal insulating layer, as found in Calamagrostis canadensis competition [5].

Spruce species response was also influenced by vegetation complex. On site 1 , the significant Competition $\times$ Species interaction (Tab. II) reveals that black spruce is more affected 
by weedy competition than white spruce. In a two-year study on abandoned agricultural land of Québec, Lemieux and Delisle [17] also observed a better resistance of white spruce to weed competition compared to black spruce.

On sites where survival is not uniformly high, seedling size is often positively related to survival $[30,32]$. On our study sites, average survival rate was greater than $80 \%$ and stock size had a minor impact on survival. Also, spruce seedling survival was not affected by competition during the first five years after planting (data not shown). However, eight years after plantation, survival was significantly affected by severe competition on site 3 . This confirms that early evaluation of spruce survival should not be used as a criterion for assessing the severity of competition or for prescribing a release treatment [12].

\section{Silvicultural implications}

The "optimum" seedling is defined as the stock that will minimize overall reforestation costs while achieving established goals for initial survival and growth [32]. By removing the competitive effects of vegetation on seedling growth and by monitoring the cumulative competitive effects over a eightyear period, the experimental design used in this study allowed an evaluation of the net benefit of planting larger seedlings in two contrasting competing environments, for the purpose of selecting an "optimum" seedling size in relation to a given vegetation cover.

Plantation of large spruce seedling stock is recommended first, because of their higher growth potential and second, because of their higher competitive ability. Increasing the initial size beyond the morphological characteristics of the $340 \mathrm{cc}$ stock is questionable, in view of the relatively low additional benefit in terms of growth obtained from planting larger stock sizes, compared to the one obtained with the 340 cc stock.

When considering competing vegetation, planting large spruce stock could compensate for the release treatment, or postpone it to the time of the pre - commercial thinning treatment (corresponding to a mean spruce height of $1.5 \mathrm{~m}$ in Québec), or avoid repetitive mechanical release treatments. For example, on site 1, plantation of the $340 \mathrm{cc}$ stock could effectively compensate for the release treatment. In terms of height, planting the $340 \mathrm{cc}$ stock with competition was equal to planting the $110 \mathrm{cc}$ stock free from competition during the first eight years. Nevertheless, by planting a $340 \mathrm{cc}$ stock with no vegetation control, the mean volume index after eight years was 2.2 times greater than planting a $110 \mathrm{cc}$ stock with no vegetation control. This illustrates the higher competitive ability of the large stock. On site 3, plantation of the 340 cc stock could potentially decrease the number of mechanical release treatments needed to maintain light availability for spruce seedlings above $60 \%$ of full sunlight [8]. In terms of both height and diameter, planting a $340 \mathrm{cc}$ stock with competition was superior to planting a $110 \mathrm{cc}$ stock mechanically released the third year. The $110 \mathrm{cc}$ stock suffered much more from competitive effects than did the $340 \mathrm{cc}$ stock. The lack of response to the release treatment for the $110 \mathrm{cc}$ standard stock size on site 3 indicates that small seedlings have reached the critical-period threshold and weed control should have occurred earlier [42]. Considering that the effects of competition increase with greater duration of limited resources availability [2], as shown in the present study for light availability with respect to stock sizes, the need to control vegetation by monitoring the competition-crop relationships is confirmed [8, 14]. In addition to effects on light availability, our results indicate that release treatments of boreal or sub-boreal spruce plantations should take into account effects on soil temperature, an often overlooked beneficial effect of this treatment. Also, planting in the spring following harvest will allow spruce seedlings to take advantage of favourable light and soil temperature conditions and contribute to delay potential negative effects of competition on spruce growth.

The need for research studies aimed at evaluating the interactions between forest nursery and silvicultural practices will likely increase in the near future [34]. Nursery practices play a major role in the success of any reforestation program and this study, among others, demonstrated the strong interaction with silvicultural treatments. Research to evaluate the benefits of planting various large spruce stock types in relation to mechanical site preparation will help to define conditions for which a mechanical site preparation is needed when large spruce stock are planted [38]. Research studies are also needed to determine the precise benefits of using genetically improved material [22] by integrating this variable in interactive studies involving silvicultural treatments.

Acknowledgements: The authors sincerely thank staff members of the Ministère des Ressources naturelles, de la Faune et des Parcs du Québec: Jacques Carignan and Réjean Poliquin for skilful technical assistance, Lise Charette and France Savard for statistical analysis, Benoît-Marie Gingras, Normand Gendron and staff from Laboratoire scientifique. We are also indebted to Daniel Saint-Hilaire (Société sylvicole Arthabaska-Drummond), Gérald Baril (Richard Pelletier \& Fils) as well as numerous undergraduate students from Université Laval. We are grateful to two anonymous reviewers for their valuable comments.

\section{REFERENCES}

[1] Brand D.G., Janas P.S., Growth and acclimation of planted white pine and white spruce seedlings in response to environmental conditions, Can. J. For. Res. 18 (1988) 320-329.

[2] Fleming R.A., Wood J.E., Modelling the effects of herbicide release on early growth and survival of Picea mariana, N. Z. J. For. Sci. 26 (1996) 202-221.

[3] Groot A., King K.M., Modeling the physical environment of tree seedlings on forest clearcuts, Agric. For. Meteorol. 64 (1993) 161185 .

[4] Grossnickle S.C., Ecophysiology of Northern Spruce Species. The Performance of Planted Seedlings, NRC Research Press, Ottawa, Ontario, Canada, 2000.

[5] Hogg E.H., Lieffers V.J., The impact of Calamagrostis canadensis on soil thermal regimes after logging in northern Alberta, Can. J. For. Res. 21 (1991) 387-394.

[6] Hungerford R.D., Babbitt R.E., Overstory removal and residue treatments affect soil surface, air, and soil temperature: implications for seedling survival, Research Paper INT-377, USDA For. Serv., 1987

[7] Jobidon R., Measurement of light transmission in young conifer plantations: A new technique for assessing herbicide efficacy, North. J. Appl. For. 9 (1992) 112-115. 
[8] Jobidon R., Light threshold for optimal black spruce (Picea mariana) seedling growth and development under brush competition, Can. J. For. Res. 24 (1994) 1629-1635.

[9] Jobidon R., Autécologie de quelques espèces de compétition d'importance pour la régénération forestière au Québec : Revue de littérature, Mémoire de recherche 117, Ministère des Ressources naturelles du Québec, Québec, 1995.

[10] Jobidon R., Pin cherry sucker regeneration after cutting, North. J. Appl. For. 14 (1997) 117-119.

[11] Jobidon R., Stump height effects on sprouting of mountain maple, paper birch and pin cherry - 10 year results, For. Chron. 73 (1997) 590-595.

[12] Jobidon R., Density-dependent effects of northern hardwood competition on selected environmental resources and young white spruce (Picea glauca) plantation growth, mineral nutrition, and stand structural development - a 5-year study, For. Ecol. Manage. 130 (2000) 77-97.

[13] Jobidon R., Charette L., Bernier P.Y., Initial size and competing vegetation effects on water stress and growth of Picea mariana (Mill.) BSP seedlings planted in three different environments, For. Ecol. Manage. 103 (1998) 293-305.

[14] Küßner R., Reynolds P.E., Bell F.W., Growth response of Picea mariana seedlings to competition for radiation, Scand. J. For. Res. 15 (2000) 334-342.

[15] Lamhamedi M.S., Bernier P.Y., Hébert C., Effect of shoot size on the gas exchange and growth of containerized Picea mariana seedlings under different watering regimes, New For. 13 (1997) 209-223.

[16] Lamhamedi M.S., Bernier P.Y., Hébert C., Jobidon R., Physiological and growth responses of three sizes of containerized Picea mariana seedlings outplanted with and without vegetation control, For. Ecol. Manage. 110 (1998) 13-23.

[17] Lemieux C., Delisle C., Using cover crops to establish white and black spruce on abandoned agricultural lands, Phytoprotection 79 (1998) 21-33.

[18] Littell R.C., Milliken G.A., Stroup W.W., Wolfinger R.D., SAS System for Mixed Models, SAS Institute Inc., Cary, 1996.

[19] Lopushinsky W., Max T.A., Effect of soil temperature on root and shoot growth and on budburst timing in conifer seedling transplants, New For. 4 (1990) 107-124.

[20] Mason E.G., A model of the juvenile growth and survival of Pinus radiata $\mathrm{D}$. Don - Adding the effects of initial seedling diameter and plant handling, New For. 22 (2001) 133-158.

[21] Mason E.G., South D.B., Weizhong Z., Performance of Pinus radiata in relation to seedling grade, weed control, and soil cultivation in the central North Island of New Zealand, N. Z. J. For. Sci. 26 (1996) 173-183.

[22] Mercier S., Périnet P., The second generation seed orchard research project at the Direction de la recherche forestière in Québec, For Chron. 74 (1998) 181-184.

[23] Mitchell R.J., Zutter B.R., South D.B., Interaction between weed control and loblolly pine, Pinus taeda, seedling quality, Weed Technol. 2 (1988) 191-195.

[24] Nelson D.G., Restocking with Sitka spruce on uncultivated gley soils - The effects of fencing, weeding and initial plant size on survival and growth, Scott. For. 44 (1990) 266-272.

[25] Newton M., Cole E.C., White D.E., Tall planting stock for enhanced growth and domination of brush in the Douglas-fir region, New For. 7 (1993) 107-121.
[26] Overton W.S., Ching K.K., Analysis of differences in heigh growth among populations in a nursery selection study of Douglas fir, For. Sci. 24 (1978) 497-509.

[27] Perreault F.N., Brouillette J.-G., Robert D., Québec new policy No herbicides, larger seedlings - Rationale and economics, Proceedings of the 1993 Forest Nursery Association of British Columbia Meeting, Courtenay, B.C., 1993.

[28] Saucier J.P., Bergeron J.F., Grondin P., Robitaille A., Les régions écologiques du Québec méridional ( $3^{\mathrm{e}}$ version), Supplément de l'Aubelle No. 124, 1998.

[29] Soil Classification Working Group, The Canadian System of Soil Classification (3rd ed.), Publ. 1646, Agriculture and Agri-Food Canada, Ottawa, 1998

[30] South D.B., Rationale for growing southern pine seedlings at low seedbed densities, New For. 7 (1993) 63-92.

[31] South D.B., Mason W.L., Influence of differences in planting stock size on early height growth of Sitka spruce, Forestry 66 (1993) 83-96.

[32] South D.B., Mitchell R.J., Determining the "optimum" slash pine seedling size for use with four levels of vegetation management on a flatwoods site in Georgia, USA, Can. J. For. Res. 29 (1999) 10391046.

[33] South D.B., Rakestraw J.L., Lowerts G.A., Early gains from planting large-diameter seedlings and intensive management are additive for loblolly pine, New For. 22 (2001) 97-110.

[34] South D.B., Rose R.W., McNabb K.L., Nursery and site preparation interaction research in the United States, New For. 22 (2001) 43-58.

[35] South D.B., Zwolinski J.B., Donald D.G.M., Interactions among seedling diameter grade, weed control, and soil cultivation for Pinus radiata in South Africa, Can. J. For. Res. 23 (1993) 2078 2082.

[36] Stewart J.D., Bernier P.Y., Gas exchange and water relations of 3 sizes of containerized Picea mariana seedlings subjected to atmospheric and edaphic water stress under controlled conditions, Ann. Sci. For. 52 (1995) 1-9.

[37] Ter Mikaelian M.T., Wagner R.G., Bell F.W., Shropshire C., Comparison of photosynthetically active radiation and cover estimation for measuring the effects of interspecific competition on jack pine seedlings, Can. J. For. Res. 29 (1999) 883-889.

[38] Thiffault N., Jobidon R., Munson A.D., Performance and physiology of large containerized and bare-root spruce seedlings in relation to scarification and competition in Québec (Canada), Ann. For. Sci. 60 (2003) 645-655.

[39] Van Wijk W.R., Soil microclimate, its creation, observation and modification, Meteorol. Monogr. 6 (1965) 59-73.

[40] Vapaavuori E.M., Rikala R., Ryyppo A., Effects of root temperature on growth and photosynthesis in conifer seedlings during shoot elongation, Tree Physiol. 10 (1992) 217-230.

[41] Vitousek P.M., Melillo J.M., Nitrate losses from disturbed forests: patterns and mechanisms, For. Sci. 25 (1979) 605-619.

[42] Wagner R.G., Mohammed G.H., Noland T.L., Critical period of interspecific competition for northern conifers associated with herbaceous vegetation, Can. J. For. Res. 29 (1999) 890-897.

[43] Zwolinski J.B., South D.B., Cunningham L., Christie S., Weed control and large bare-root stock improve early growth of Pinus radiata in South Africa, N. Z. J. For. Sci. 26 (1996) 163-172. 